\title{
INTERFACE DO PORTUGUÊS COM A LÍNGUA DE SINAIS EM PUBLICAÇÕES DE UM PROFESSOR SURDO EM REDE SOCIAL
}

\author{
Aryane Santos Nogueira* \\ Universidade Estadual de Campinas \\ Faculdade de Educação \\ Campinas, SP, Brasil
}

\begin{abstract}
Resumo: $O$ artigo focaliza a interface do português com a língua de sinais em publicações realizadas por um professor surdo em sua página pessoal na rede social Facebook durante $o$ ano de 2017. A motivação para o recorte ocorreu pela possibilidade de observação de práticas comunicativas constitutivas da participação social de usuários surdos. A partir de uma análise qualitativo-interpretativa, informada teoricamente por uma concepção sociolinguística ampliada do conceito de língua(gem), explora-se o conjunto de publicações e o engajamento do público via comentários para mostrar especificidades sobre a interação que se estabelece entre os recursos linguísticos do português e da língua de sinais empregados. Interseccionadas também por recursos semióticos amplamente utilizados na internet (imagens, memes, gifs), tais interações evidenciam um conceito de multilinguismo mais complexo, entremeado a construções ideológicas sobre a língua(gem) e sobre a pessoa surda.
\end{abstract}

Palavras-chave: Surdez. Multilinguismo. Português. Língua de sinais. Ambiente digital online.

\section{INTRODUÇÃO}

Neste artigo exploramos interações em ambiente digital online dando continuidade ${ }^{1}$ a um movimento que consideramos relevante para os estudos que se debruçam sobre a comunicação de pessoas surdas: a construção de entendimentos sobre os repertórios sociossemióticos e o uso de recursos semióticos multilíngues e multimodais em situações de comunicação (com base em KUSTERS et al., 2017). Para isso, analisamos um conjunto de publicações de um professor surdo em sua página pessoal na rede social Facebook ao longo do ano de 2017 e as interações via comentários disparadas por suas postagens. Nesse caminho, mostramo-nos alinhados a Dovchin e Pennycook (2018), ao ressaltarem que estudiosos das práticas de linguagem online já têm enfatizado a diversidade e heterogeneidade linguística e semiótica como características cruciais das interações nesses espaços. Sendo assim, ao observarmos as estratégias linguísticas e

\footnotetext{
* Doutora em Linguística Aplicada na área de Multiculturalismo, Plurilinguismo e Educação Bilíngue pela Universidade Estadual de Campinas. Docente do Programa de Pós-graduação em Educação. (FE/UNICAMP). Digital identifier ORCID: <https://orcid.org/0000-0002-8679-5240>. E-mail: aryane@unicamp.br.

${ }^{1}$ Nogueira (2014) e Nogueira (2015) são exemplos de outros trabalhos que, de algum modo, exploraram o multilinguismo e a multimodalidade no contexto da surdez.
} 
semióticas que combinam diferentes recursos, modos, repertórios e estilos em ambientes online como o Facebook, estamos atentos à possibilidade de colaborar com a necessidade crescente de problematizar e complexificar, por exemplo, conceitos mais tradicionais de bi/multilinguismo no contexto da surdez e oferecer entendimentos mais matizados sobre as interações translíngues (CANAGARAJAH, 2017) de pessoas surdas, cujas trajetórias são sócio-histórica e linguisticamente complexas (CAVALCANTI, 2011) e fragmentadas (BLOMMAERT, 2010).

Em específico, nos dedicaremos à questão da interface entre a língua de sinais e o português escrito, recursos linguísticos que compõem os repertórios sociossemióticos observados. Isso porque, nos estudos sobre a surdez, essa interface tem sido entendida por alguns autores como interferência (FERNANDES, 2007, p. 19) da primeira na segunda língua, como uma interlíngua (BROCHADO, 2003, p. 142) que, em sua provisoriedade, serviria de apoio ou degrau (PEIXOTO, 2006, p. 219) até que o uso esperado da língua-alvo (português escrito padrão ou nativo) fosse atingido. Esses estudos estão todos pautados em uma perceptiva bilíngue de trabalho com o surdo, no entanto, concordamos com Maher $(2016)^{2}$ quando explica que em programas bilíngues nos quais a relação entre uma língua e outra é apenas momentaneamente aceita, o que se espera, ao final, é que se chegue a um estágio de bilinguismo equilibrado ou ainda, como colocaram Cavalcanti e Silva (2016), um duplo monolinguismo.

$\mathrm{O}$ que fundamenta essa perspectiva bilíngue adotada em grande medida no campo da surdez é uma concepção de língua como entidade com fronteiras rigidamente delimitadas, que pouco contribui para avançarmos no sentido de lançar luzes sobre a coleção de recursos que, em interação e não em interferência, são base para a produção de significados pelos surdos. Salientamos ainda que, embora existam outras propostas bilíngues de manutenção, que avancem no sentido de valorização dos recursos linguísticos, elas ainda se fundam numa noção de línguas como recursos estanques e passam ao largo de considerar outros recursos semióticos nos processos de comunicação das pessoas surdas.

Nas seções seguintes, apresentamos a fundamentação teórico-metodológica que alicerçou a análise e as discussões empreendidas no trabalho, além de descrevermos o desenho metodológico que guiou a geração de registros e a construção dos dados analisados. Destacamos que serão apresentados aspectos mais gerais sobre a composição das publicações analisadas, uma vez que consideramos que eles estão diretamente relacionados aos aspectos específicos que constituíram o engajamento dos interlocutores com as postagens e a interação entre um ou mais recursos componentes dos repertórios sociossemióticos empregados. Ao final, elencamos algumas particularidades a respeito da interface português-língua de sinais observada, argumentando em favor da compreensão do conceito de interface no sentido de interação entre esses recursos.

\footnotetext{
2 Notas realizadas durante a apresentação intitulada "Políticas linguísticas e as línguas minoritárias brasileiras: a necessária reversão de uma certa lógica" durante o II Colóquio Língua, Discurso e Poder realizado na Universidade Federal de São Carlos (UFSCar).
} 


\section{PRÁTICAS TRANSLÍNGUES E OS REPERTÓRIOS SOCIOSSEMIÓTICOS NO CONTEXTO DA SURDEZ}

Uma concepção sociolinguística ampliada do conceito de língua(gem) emergiu da recorrente tematização do próprio conceito de língua nos estudos sociolinguísticos sobre o multilinguismo e as práticas de comunicação e produção de significados na contemporaneidade (ver, por exemplo, MARTIN-JONES; BLACKLEDGE; CREESE, 2012). Observamos uma mudança substancial nos modos de descrever e explicar a natureza complexa das práticas comunicativas de pessoas em fluxos e capazes de interagir com diferentes línguas(gens) utilizando também uma multiplicidade de canais, sejam eles próximos, como a comunicação face a face, ou distantes, via tecnologias de comunicação. Como bem colocou Jacquemet (2015), o multilinguismo perdeu seu caráter de desvio da norma.

De acordo com Canagarajah (2017, p. 2), assim como já apontaram Blackledge (2000), Blommaert e Rampton (2011) e Martin-Jones, Blackledge e Creese (2012) ${ }^{3}$, essas foram mudanças graduais que distanciaram concepções sociolinguísticas mais atuais do paradigma estruturalista da linguística moderna, cujos construtos colaboraram de maneira significativa para a invenção e manutenção de projetos essencializadores da relação língua-Nação ou de grupos sociais com práticas linguísticas específicas, territorializando e tornando a língua propriedade de determinados grupos e/ou espaços. Nesse sentido, a noção de translinguismo, para Canagarajah (2017, p. 9), desafiou modelos tradicionais, colaborando com um olhar para os recursos verbais nas práticas comunicativas que transcendia a noção de línguas autônomas. Mais recentemente, ainda segundo o autor, esse conceito passou a abarcar outros recursos semióticos e modalidades como parte de uma coleção que integra as situações de comunicação e os significados.

A ideia de coleção, de acordo com Canagarajah (2017, p. 9), ainda nos ajuda no entendimento do papel colaborativo que os diversos recursos semióticos e linguísticos assumem para o sucesso da atividade comunicativa, atividade na qual todas as modalidades interagem entre si, atuam em conjunto e modelam umas às outras.

O entendimento da questão linguística no contexto da surdez não escapou da lógica estruturalista, uma vez que, como apresentamos na introdução, há um modelo mais tradicional de bilinguismo - ainda presente na grande maioria dos trabalhos e que fundamenta, inclusive, a legislação na área ${ }^{4}$-, compreendido como um sistema composto por duas línguas muito bem delimitadas: a língua brasileira de sinais (libras), com caráter de primeira língua, e a língua portuguesa (na modalidade escrita), como segunda língua. De fato, esses dois recursos podem estar presentes na vida do surdo, mas constituem, de maneiras muito particulares, os repertórios sociossemióticos de cada um dos indivíduos.

Cavalcanti (2011) reconhece que os contextos bi/multilíngues de minorias, como o da surdez, têm, muitas vezes, uma complexidade que não é, de imediato, identificada: no caso dos surdos, há que se considerar que o português pode estar presente em uma variedade menos prestigiada e/ou na variedade ensinada na escola. A língua de sinais

\footnotetext{
${ }^{3}$ Cabe esclarecer que os autores listados, assim como Canagarajah (2017), não focalizam o contexto da surdez em seus trabalhos. No entanto, as discussões sobre o multilinguismo por eles apresentadas permitem, a nosso ver, aproximações com o contexto multilíngue das pessoas surdas.

${ }^{4}$ Lei Federal $n^{\circ} 10.436 / 02$ e decreto $n^{\circ} 5.626 / 05$, entre outras.
} 
também está presente em suas variedades, assim como outras gestualidades ou linguagens podem aparecer, como é o caso das línguas de sinais caseiras. Nem sempre a língua de sinais será a primeira língua e o português, a segunda ${ }^{5}$, e como estamos falando de sujeitos que são bi/multilíngues, é natural que os recursos linguísticos que compõem seus repertórios comunicativos interfiram uns nos outros, como no caso do português surdo que se constrói numa relação constante com a língua de sinais. Assim, entendemos que essas possíveis mesclas não são prejudiciais à comunicação e nem transitórias, mas se constituem naturalmente em contextos multilíngues a partir do momento em que a geração de entendimentos compartilhados se faz central (cf. CAVALCANTI; SILVA, 2016).

Consideramos o exposto e, ao compreendermos as práticas de comunicação e produção de significados no contexto da surdez, adotamos orientação semelhante à dos autores apresentados nesta seção, vinculados ao que estamos considerando uma perspectiva sociolinguística complexa e ampliada das práticas comunicativas na atualidade. Seguimos adiante e argumentamos, tal como Kusters (2017) e Kusters et al. (2017) - que pesquisam a comunicação de pessoas surdas indianas -, sobre a possibilidade de que tais práticas sejam compreendidas a partir de um quadro de referências que permita considerar o conceito de repertório comunicativo em seu caráter sociossemiótico, multilíngue e multimodal, isto é, não mais como sistema de línguas delimitadas, nem mesmo concebido apenas por recursos linguísticos, já que ele também pode incluir diversos recursos semióticos multimodais, corporificados e do ambiente em interação.

É ainda nesse mesmo sentido que também nos apresentamos como motivados pelas noções de práticas translíngues e de coleção de Canagarajah (2017) e passamos a nos debruçar sobre a interface do português com a língua de sinais nas publicações de um professor surdo. Concebendo-a como interação entre recursos, parte do processo natural de estratégias comunicativas que o indivíduo multilíngue pode experimentar, tentamos compreender quais seriam algumas das especificidades dessa interface.

\section{ASPECTOS METODOLÓGICOS}

Trazemos o relato do recorte de uma pesquisa maior ${ }^{6}$ em andamento, afiliada a uma vertente indisciplinar da Linguística Aplicada (MOITA LOPES, 2006) e de caráter qualitativo-interpretativista (MOITA LOPES, 1994). Considerando a perspectiva assumida, não pretendemos em nenhum momento homogeneizar ou construir generalizações a partir da realidade estudada, mas sim considerar o caráter situado e a natureza sócio-histórica do conhecimento produzido (SIGNORINI, 1998).

\footnotetext{
${ }^{5}$ Mais recentemente, temos feito a opção pelos termos língua matriz e língua adicional.

${ }^{6}$ A pesquisa foi realizada durante o trabalho de levantamento e tratamento das referências bibliográficas para o projeto de pesquisa intitulado "Repertórios semióticos e educação de surdos: multilinguismo e multimodalidade no contexto de línguas de sinais" (processo $\mathrm{n}^{\circ}$ 17/20256-0), financiado pela FAPESP e aprovado pelo Comitê de Ética (CAAE 73275317.0.0000.5404). A intenção foi realizar uma breve sondagem da participação dos surdos em ambiente digitais online para auxiliar na composição de um quadro da complexidade sociolinguística no contexto da surdez.
} 
O corpus de análise da pesquisa foi constituído por um total de 320 publicações de um professor surdo em sua página pessoal na rede social Facebook durante o ano de 2017. ${ }^{7}$ Esse número corresponde ao total de postagens realizadas pelo professor ao longo do ano, excluídas as marcações feitas por outros usuários (113 marcações), que também estão visíveis em sua página. Nesse caminho, aspectos sobre a interface do português e da língua de sinais, foco deste artigo, iluminaram-se a partir das respostas para a seguinte pergunta de pesquisa: quais são as estratégias linguísticas e semióticas do professor surdo e de seus interlocutores? Isto é, analisando as publicações do professor surdo em sua rede social e as interações via comentários, quais e como são empregados os recursos linguísticos e semióticos que compõem os repertórios sociossemióticos? E mais, como se configuram as interações quando elas envolvem uma gama ampla de recursos?

Após a leitura do total de publicações, realizamos o exame quantitativo e qualitativo dos registros. Esse passo foi fundamental para a organização e a construção dos dados a serem analisados. Nesse processo, percebemos a possibilidade de que o conjunto maior de registros fosse categorizado em três diferentes eixos temáticos, conforme apresentado no Quadro 1 seguinte.

\section{Quadro 1 - Eixos temáticos das publicações do professor surdo}

\begin{tabular}{|c|c|c|}
\hline \multicolumn{3}{|c|}{ Eixos temáticos das publicações } \\
\hline Político & Pessoal & Informativo \\
\hline $\begin{array}{l}\text { As postagens referem-se, } \\
\text { sobremaneira, à filiação política do } \\
\text { professor e sua possível escolha de } \\
\text { candidato à presidência para as } \\
\text { eleições do ano de } 2018 \text {. Aparecem } \\
\text { publicações com conteúdos de } \\
\text { denúncia e repúdio a determinados } \\
\text { partidos e/ou políticos. }\end{array}$ & $\begin{array}{l}\text { Contém postagens com aspectos da } \\
\text { vida pessoal do professor (vídeos, } \\
\text { passeios, participação em eventos, } \\
\text { seu aniversário e de familiares etc.) } \\
\text { e também sobre temática de super- } \\
\text { heróis. O professor demonstra seu } \\
\text { interesse, compartilhando produtos } \\
\text { e imagens relacionados a esse super- } \\
\text { herói ou mesmo aparece vestido } \\
\text { com uma camiseta que remete à } \\
\text { vestimenta do personagem. }\end{array}$ & $\begin{array}{l}\text { As postagens compartilham notícias } \\
\text { e informações de interesse para os } \\
\text { participantes com os quais o } \\
\text { professor interage - sempre há uma } \\
\text { chamada ou comando para despertar } \\
\text { a atenção dos interlocutores. Muitas } \\
\text { das informações compartilhadas } \\
\text { dizem respeito a novas tecnologias } \\
\text { (que podem ou não estar diretamente } \\
\text { relacionadas a algum aspecto da } \\
\text { surdez) e assuntos cotidianos que } \\
\text { são de interesse para pessoas surdas. }\end{array}$ \\
\hline
\end{tabular}

Fonte: dados produzidos pela autora.

A leitura das publicações também permitiu que observássemos quais tipos de recursos linguísticos e semióticos constituíram as postagens do professor. Constatamos e categorizamos três categorias de postagens quanto à predominância ${ }^{8}$ de recursos empregados. Observamos que algumas das publicações foram feitas com recursos predominantemente visuais, por meio da postagem de fotos e imagens, por exemplo. Outras publicações apresentaram postagens com recursos visuais associados a recursos linguísticos da língua de sinais e/ou do português, como vídeos em língua de sinais, vídeos legendados em português ou ainda vídeos com janela de libras. Os vídeos com janela de tradução em libras, embora apresentassem o recurso linguístico do português

\footnotetext{
${ }^{7} \mathrm{O}$ recorte temporal justifica-se pelo fato de considerarmos o período suficientemente abrangente para podermos construir entendimentos sobre as estratégias linguísticas e semióticas do sujeito.

8 Optamos por categorizar as publicações quanto à predominância do recurso na postagem, sem desconsiderarmos, no entanto, o caráter multissemiótico que constitui os textos que circulam nos ambientes digitais online.
} 
oral junto à tradução em língua de sinais disponível na janela, foram considerados na categoria predominância da língua de sinais, uma vez que observamos que sempre que um vídeo desse tipo era postado, ele vinha com uma legenda escrita pelo professor surdo destacando a existência da janela de tradução no vídeo. Ainda que dimensionalmente menor, em termos do tamanho da imagem da janela em comparação com o restante do vídeo, ao chamar a atenção para tal recurso, o professor parece destacar a importância que esse recurso assume para ele e seus interlocutores. Considerando essas observações, os dados foram categorizados como apresentado no Quadro 2.

\begin{tabular}{|c|c|c|}
\hline \multicolumn{3}{|c|}{ Tipos de postagens } \\
\hline $\begin{array}{c}\text { Predominância } \\
\text { visual } \\
\end{array}$ & $\begin{array}{c}\text { Predominância } \\
\text { Português }\end{array}$ & $\begin{array}{c}\text { Predominância } \\
\text { Língua de Sinais } \\
\end{array}$ \\
\hline $\begin{array}{l}\text { Foto } \\
\text { Imagem } \\
\text { Vídeo somente imagético (sem } \\
\text { recursos linguísticos escritos ou } \\
\text { sonoros) }\end{array}$ & $\begin{array}{l}\text { Imagem com português escrito (p. } \\
\text { ex., memes) } \\
\text { Link de notícia em português escrito } \\
\text { (título principal e auxiliar em } \\
\text { português escrito, acompanhados de } \\
\text { uma fotografia ou imagem) } \\
\text { Texto escrito (em português, } \\
\text { geralmente de autoria do professor) } \\
\text { Vídeo legendado (vídeo em } \\
\text { português ou inglês oral e com } \\
\text { legenda em português) } \\
\text { Vídeo oral sem legenda (vídeo em } \\
\text { português oral sem legenda) }\end{array}$ & $\begin{array}{l}\text { Vídeo em língua brasileira de sinais } \\
\text { (libras) } \\
\text { Vídeo em outras línguas de sinais } \\
\text { Vídeos com janela de tradução para } \\
\text { língua de sinais }\end{array}$ \\
\hline
\end{tabular}

Fonte: dados produzidos pela autora.

A categorização das publicações (apresentadas por meio de captura de tela na seção 5 adiante) quanto aos diferentes eixos temáticos e aos tipos de recursos predominantes nas postagens auxiliaram no processo de compreensão das estratégias linguísticas e semióticas do professor e dos seus interlocutores, também relacionadas ao próprio conjunto de recursos com o qual, por meio das publicações, eles interagiram.

\section{ANÁLISE DE DADOS: ASPECTOS GERAIS}

Como um aspecto geral das publicações do professor, destacamos um repertório sociossemiótico que envolve a língua de sinais e a língua portuguesa, mas que também é composto por outros recursos semióticos.

Durante o ano de 2017, como pode ser visto no Gráfico 1 a seguir, as postagens do professor surdo foram direcionadas, sobretudo, aos eixos pessoal, com um total de 145 postagens, $45,3 \%$ do total de publicações no ano, e político, com 144 postagens, correspondentes a $45 \%$ do total de publicações. O eixo informativo se manteve com a menor porcentagem, apenas $9,7 \%$, correspondendo a 31 postagens. 


\section{Gráfico 1 - Postagens por eixo ao longo de 2017}

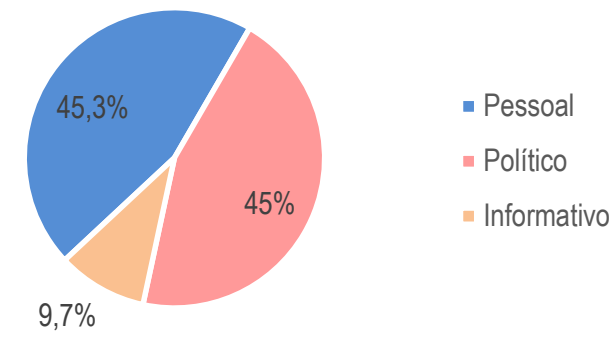

Fonte: dados produzidos pela autora.

Como apresentado na seção de descrição da metodologia, dentro dos eixos informativo, pessoal e político, observamos postagens de três tipos: com recursos essencialmente visuais, postagens com predominância de recursos linguísticos do português e postagens com predominância de recursos linguísticos da língua de sinais. No Gráfico 2 que segue, visualizamos que houve um maior número de postagens, $48 \%$ do total, nas quais predominaram os recursos linguísticos do português, como imagens acompanhadas de texto escrito (16\%), vídeos em português ou inglês oral e legendados (14\%), textos escritos em português (8\%), links de notícias (7\%) e vídeos orais sem legenda (3\%).

O professor surdo é sinalizante e tem a língua de sinais como sua língua matriz. Observamos que as postagens que se valeram desse recurso linguístico corresponderam a $27 \%$ do total. Nessa categoria, os vídeos em libras apareceram em maior quantidade (24\%), enquanto os vídeos com janela de tradução (2\%) e vídeos em outras línguas de sinais $(1 \%)$ apareceram em menor quantidade.

\section{Gráfico 2 - Porcentagem de recursos utilizados nas postagens}

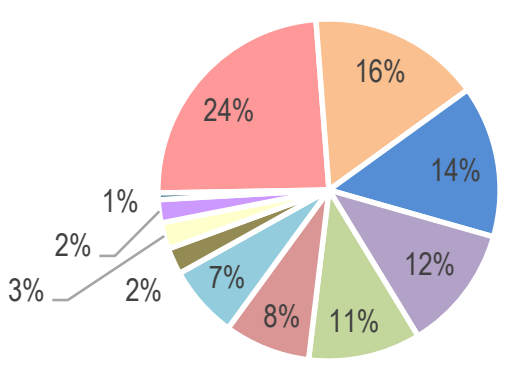

$$
\begin{aligned}
& \text { - Vídeo língua de sinais } \\
& \text { - Imagem com português } \\
& \text { - Vídeo legendado } \\
& \text { - Foto } \\
& \text { - Imagem } \\
& \text { - Texto escrito } \\
& \text { - Link de notícia } \\
& \text { - Vídeo com janela } \\
& \text { Vídeo oral sem legenda } \\
& \text { - Vídeo imagético } \\
& \text { - Vídeo outras línguas de sinais }
\end{aligned}
$$

Fonte: dados produzidos pela autora.

Sobre esses dois aspectos destacamos que, embora as postagens em português tenham predominado sobre as postagens em língua de sinais, as primeiras não predominaram sobre o total geral de postagens com recursos visuais, sejam eles linguísticos (materiais em língua de sinais - cf. Quadro 2) e/ou semióticos (materiais essencialmente visuais - cf. Quadro 2). Isso significa que, ao somarmos os $27 \%$ de 
postagens com predominância de recursos da língua de sinais - considerando a modalidade visual desta língua - aos valores das postagens com recursos visuais, isto é, $25 \%$ do total de postagens ( $12 \%$ de fotos, $11 \%$ de imagens e $2 \%$ de vídeos imagéticos), percebemos que $52 \%$ das publicações realizadas pelo professor foram constituídas de materiais com recursos linguísticos e semióticos visuais.

A leitura extensiva das publicações do professor surdo, junto à leitura conjunta dos dados que aparecem nos Gráficos 1 e 2, nos deram indicações de que a alta porcentagem de postagens com predominância de recursos linguísticos em português está relacionada ao fato de que esse recurso foi recorrente em todos os eixos de postagem, aparecendo nos eixos pessoal e informativo com menor frequência, mas sendo predominante no eixo político, segundo eixo com maior número de postagens realizadas pelo professor. Nesse eixo, muitos dos materiais foram publicados na forma de compartilhamento e envolviam memes e vídeos legendados com gravações de sessões políticas. Além disso, o professor compartilhou muitos links de notícias, e grande parte dos textos escritos por ele também apareceu com teor político, em forma de atualização de status do usuário. Nos eixos informativo e, sobretudo, pessoal, a maioria de suas postagens foi em formato de vídeo em língua de sinais.

Sobre esse aspecto, destacamos que a quantidade de conteúdos em língua de sinais disponível online vem crescendo nos dias de hoje, dentre outros fatores, pela intensificação do acesso à internet e, ao mesmo tempo, pela grande participação de pessoas surdas e não surdas nas mais variadas plataformas digitais, produzindo e compartilhando materiais diversos em língua de sinais. No entanto, sabemos que esse número ainda não é maior que a quantidade de conteúdos em português (seja escrito ou oral) que circulam no ambiente digital. Ao mesmo tempo que assumimos que esse pode ter sido um fator que contribuiu para o alto número de publicações com predominância de recursos do português, não deixamos de considerar que, ao compartilhar publicações em português, o professor também nos dá um indicativo das representações que tem a respeito de seus interlocutores, isto é, de interlocutores capazes de interagir com esse recurso.

Há, a nosso ver, uma interface do português com a língua de sinais, caracterizada, em primeira instância, pela presença dos dois recursos linguísticos, entremeados a uma gama de outros recursos semióticos, compondo o repertório das publicações do professor. No entanto, a interação entre os dois recursos vai além da simples presença. Como explicam Dovchin e Pennycook (2018), o Facebook é um ambiente transmodal no qual os usuários redefinem o papel de língua pela mixagem com outros recursos linguísticos e com textos multimodais. Nessa esteira, como pretendemos evidenciar na seção seguinte, a interface português-língua de sinais observada envolve estratégias linguísticas e semióticas específicas dos interlocutores e relaciona-se com representações sobre a pessoa surda e sobre os próprios recursos linguísticos. Assim, a fim de iluminar algumas especificidades dessa interface, passaremos a analisar três publicações do professor.

Em todas as publicações analisadas estamos entendendo que se evidencia o caráter translíngue - no sentido ampliado de translinguismo proposto por Canagarajah (2017) das práticas comunicativas em contextos multilíngues e multissemióticos, uma vez que os sentidos dos enunciados que elas carregam não são dados exclusivamente por um ou outro recurso linguístico ou semiótico, mas são coconstruídos pela interação entre eles. 
5 ANÁLISE DE DADOS: ASPECTOS ESPECÍFICOS

A imagem da Figura 1 refere-se a uma publicação do professor surdo referente ao que categorizamos como eixo temático político. A publicação compartilha a atualização do vídeo de seu perfil por meio da adição de um tema: um filtro composto por uma faixa vermelha com os dizeres "Lula presidiário 2018", que aparece anteposta à imagem de perfil do professor. ${ }^{9}$

\section{Figura 1 - Publicação de atualização da imagem de perfil com adição de filtro}

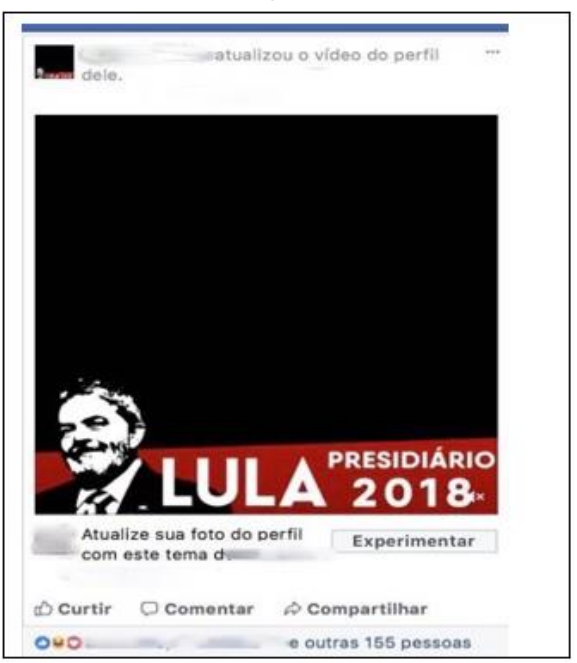

Fonte: Dados coletados pela pesquisadora na página do usuário.

Considerando que o teor político das publicações do professor surdo esteve, durante o ano de 2017 analisado, sempre alinhado a uma perspectiva crítica ao ex-presidente Lula e ao PT, a adição do filtro teve a intenção de expressar o desejo do professor de que a prisão do ex-presidente Lula se efetivasse em 2018. Ao mesmo tempo que harmoniza com o teor político de suas outras postagens, o filtro acrescenta um tom jocoso à publicação: a imagem do ex-presidente Lula e a maneira como estão dispostos os elementos linguísticos no filtro em muito se assemelham ao layout utilizado em diversos meios de publicidade política. Mas, no lugar de "Lula presidente 2018" estão os dizeres "Lula presidiário 2018" e a semelhança sonora e visual das palavras "presidente" e "presidiário" acrescentam jocosidade ao filtro.

A publicação recebeu mais de 155 curtidas e/ou reações e, além disso, foram feitos 92 comentários à postagem (ver exemplos de comentários nas Figuras 2, 3, 4, 5 e 6 a seguir). Entendemos que a intensa interação disparada pela publicação se deu não só pelo forte engajamento político que o professor demonstrou durante o ano (45\% do total de suas publicações, como apresentado na seção anterior) em suas postagens, mas,

\footnotetext{
${ }^{9}$ Qualquer usuário do Facebook pode adicionar um filtro à sua foto de perfil. Geralmente a adição de temas está relacionada a algum movimento social, como em 2015, quando o próprio Facebook disponibilizou aos usuários o tema da bandeira colorida, símbolo do movimento LGBT, para comemorar a aprovação do casamento gay pela Suprema Corte dos EUA.
} 
principalmente, pelo jogo imagético e linguístico que há no filtro. Isto é, estamos entendendo que a relação do recurso imagético junto ao recurso linguístico do português escrito orientou toda a interação via comentários e, portanto, as estratégias linguísticas e semióticas empregadas. Isso porque a intenção jocosa não foi compreendida por alguns dos interlocutores que se engajaram com a publicação do professor e passaram a postar comentários questionando os motivos pelos quais ele teria mudado seu posicionamento político de modo a votar em Lula, como se nota na Figura 2.

\section{Figura 2 - Engajamento de usuário: dúvida desencadeada pela inserção do filtro "Lula presidiário 2018"}

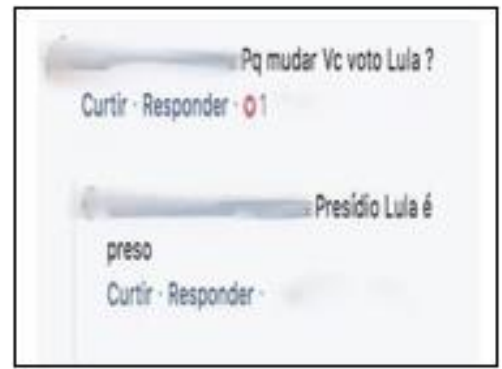

Fonte: dados coletados pela pesquisadora na página do usuário.

Assim como o exemplo disponível na Figura 2, muitos comentários adicionados à postagem questionaram a mudança de orientação política do professor, indicando que não houve, a princípio, entendimento do termo "presidiário" e da ironia presente na postagem, já que, como dito anteriormente, o professor declarou explicitamente, a partir de suas postagens, sua afiliação política. Na Figura 2, quando um dos usuários pergunta ao professor por que ele havia mudado sua escolha de candidato e passaria a votar em Lula ("Pq mudar Vc voto Lula?"), logo vemos que outro usuário responde a essa pergunta dizendo que "presidiário" significa "preso" e que, portanto, os dizeres da faixa se referiam à ação da prisão de Lula ("Presídio Lula é preso"). Esse e outros usuários, assim como o próprio professor surdo, engajaram-se na elaboração de comentários que respondiam aos interlocutores que apresentavam dúvida semelhante.

Observamos que a dificuldade em compreender a intenção da postagem do professor incitou ainda a elaboração de comentários com estratégias de apresentação dos recursos linguísticos diferentes das que já estavam sendo utilizadas, isto é, das que apenas diziam que o termo "presidiário" teria o mesmo sentido de "preso". Como pode ser visto na Figura 3, uma usuária utiliza o recurso de caixa alta para dar destaque ao fato de que o professor não votaria em Lula (“Ele NÃO vota Lula! Presidiário é preso!”). Em seguida, essa mesma usuária continua sua resposta reescrevendo a frase original da postagem e inserindo nela o vocábulo "preso", pois pode ter julgado que, quando inserido no enunciado, seu sentido seria mais facilmente compreendido pelos demais ("Lula preso 2018! Tendeu?’). 
Figura 3 - Estratégia linguística de utilização de caixa alta e reescrita dos dizeres "Lula Presidiário 2018"

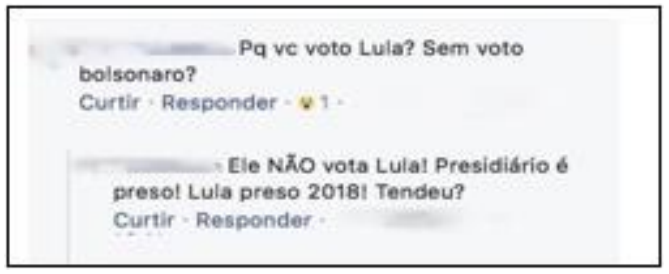

Fonte: dados coletados pela pesquisadora na página do usuário.

Cabe trazer à discussão algumas especificidades sociolinguísticas do contexto da surdez que auxiliam nossa compreensão de comentários do tipo analisado. As pessoas surdas desenvolvem uma relação com o recurso escrito muito mais a partir de seu aspecto visual do que pela noção de escrita como representação gráfica da sonoridade de uma palavra falada, como se daria para muitas pessoas ouvintes (cf. GESUELI, 2003). São vários os autores que apontam experiências de formação de pessoas surdas nas quais as práticas de leitura e escrita passam, necessariamente, pela língua de sinais como instrumento de mediação que fundamenta o trabalho com a escrita (GESUELI, 2012, p. 173) e facilita o acesso a essa modalidade da língua (GIORDANI, 2012, p. 141) por transposição ou tradução de elementos em português para língua de sinais (PEREIRA, 2012, p. 239) e vice-versa. O trabalho com a leitura e a escrita em português emergiria, portanto, como afirma Gesueli (2012, p. 176), de um entrelaçamento de capacidades linguísticas em língua de sinais e em português. Sendo assim, estamos entendendo que a incompreensão da postagem, para além da semelhança do layout do filtro com uma publicidade política, pode ter sido motivada: a) pela proximidade visual dos termos "presidente" e "presidiário" em português, sendo confundidos pelos usuários surdos pela pouca familiaridade com a língua escrita - devido ao histórico de experiências escolares de uso do recurso linguístico escrito bastante empobrecidas e b) pelo fato de que, em libras, os termos "preso", "presidiário" ou o verbo "prender" podem ser representados por um mesmo sinal, que tem seu sentido diferenciado pelo contexto de uso. Sendo assim, é bastante provável que a substituição do termo "presidiário" por "preso", nos comentários, tenha sido motivada também por esse aspecto da língua de sinais.

Considerando o que foi anteriormente exposto, entendemos que o engajamento dos surdos via comentários à postagem do professor exibe uma relação dos usuários com o português que é permeada pela língua de sinais. Nesse fato reside uma das particularidades sobre a interface entre a língua de sinais e o português, no sentido de uma interação entre os dois recursos linguísticos que emerge, portanto, da análise dessa publicação: embora os recursos linguísticos do português tenham sido os principais orientadores do engajamento com a publicação, vislumbramos que a leitura e compreensão dos elementos linguísticos em português podem ter passado pelo que aqui estamos chamando de uma lente de leitura a partir da língua de sinais, ainda que esse recurso não tenha se materializado, de fato, em nenhum dos comentários (não foram feitos comentários com vídeos em libras, por exemplo). 
O fato de o recurso linguístico do português ter sido o elemento de enquadre do engajamento nos comentários também motivou a expressão de representações específicas sobre esse recurso e seu domínio por parte de alguns usuários. Ao realizar a atualização de seu vídeo de perfil com os dizeres em português escrito, concebemos que o professor acaba antecipando interlocutores aptos a compreenderem materiais compostos por esses recursos linguísticos. Sendo assim, ao mesmo tempo que entendemos que a escolha linguística do professor pode refletir uma representação de um interlocutor (surdo) bi/multilíngue que teria a língua portuguesa como um dos recursos que comporia seus repertórios sociossemióticos, não deixamos de considerar que tal escolha, ao viabilizar a interação via comentários, tal como ela se apresentou, também permitiu que outras representações sobre o surdo e os recursos linguísticos fossem mobilizadas: tal como as considerações feitas por Karnopp (2012) sobre enaltecimento dos surdos que escrevem ou a valorização do recurso escrito por jovens surdos, observada em Nogueira (2015), no exemplo da Figura 4 a seguir, os comentários destacados são de usuários surdos que caçoam e deflagram uma representação comiserada da pessoa surda quando relacionada à sua incapacidade de compreensão dos elementos linguísticos em português ("Alguns surdos não sabe que é 'presidiário' aff kkkkkkk!!’), ao mesmo tempo que valorizam um surdo que sabe fazer um bom uso do recurso "O [nome do professor surdo] é esperto $[\ldots] "$.

\section{Figura 4 - Usuários comentando sobre as dificuldades de compreensão dos surdos}

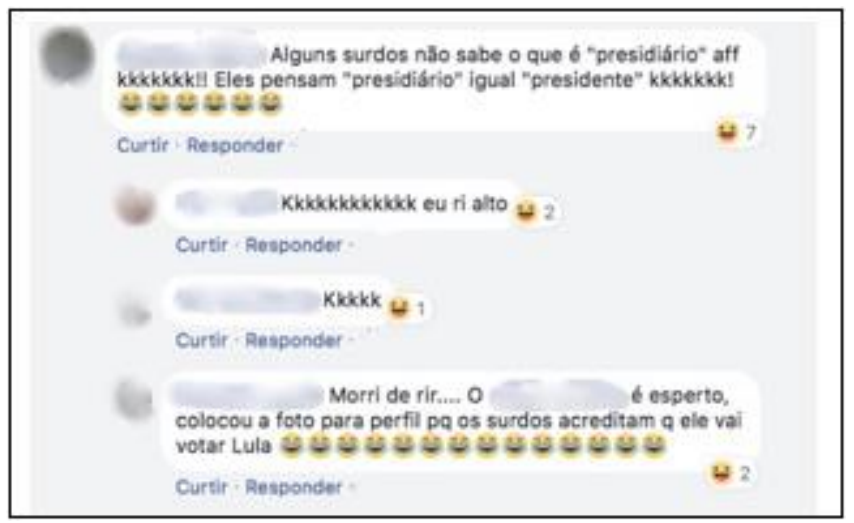

Fonte: dados coletados pela pesquisadora na página do usuário.

Embora já tenhamos mencionado o fato de o professor surdo ter respondido alguns dos comentários feitos em sua postagem, destacamos que sua interação foi reduzida. Uma de suas respostas, em especial, nos chamou a atenção, pois se deu por meio da inserção de um emoji personalizado - um boneco vestido de super-herói com uma expressão espantada e pontos de interrogação e exclamação sobre a cabeça, como exibido na Figura 5 a seguir.

A resposta do professor, como podemos ver na Figura 5, deu-se logo após mais uma usuária perguntar o significado da palavra "presidiário" ("Olá [nome do professor surdo] tudo bem?? O que é significa presidiário? Significa 'preso'????”). Quando a usuária se depara com o emoji como resposta, ela insiste e explica que quer de fato saber o significado da palavra, pois a definição apresentada pelo dicionário parece não ajudar na sua compreensão ("Sério, gostaria de te perguntar sim..."). Ela apresenta, inclusive, em seguida, dois prints da busca pelo significado das palavras "presidiário" e "presídio" no 
dicionário. Ponderamos que o pouco engajamento do professor na resposta aos comentários e o uso do emoji personalizado, espantado com a dificuldade na compreensão da publicação, parece nos confirmar que, assim como os interlocutores que comentaram as dificuldades de alguns usuários surdos, como se viu na Figura 4 anteriormente, talvez ele também não esperava encontrar tal dificuldade em seus interlocutores.

Figura 5 - Estratégias semióticas de utilização de emojis e prints

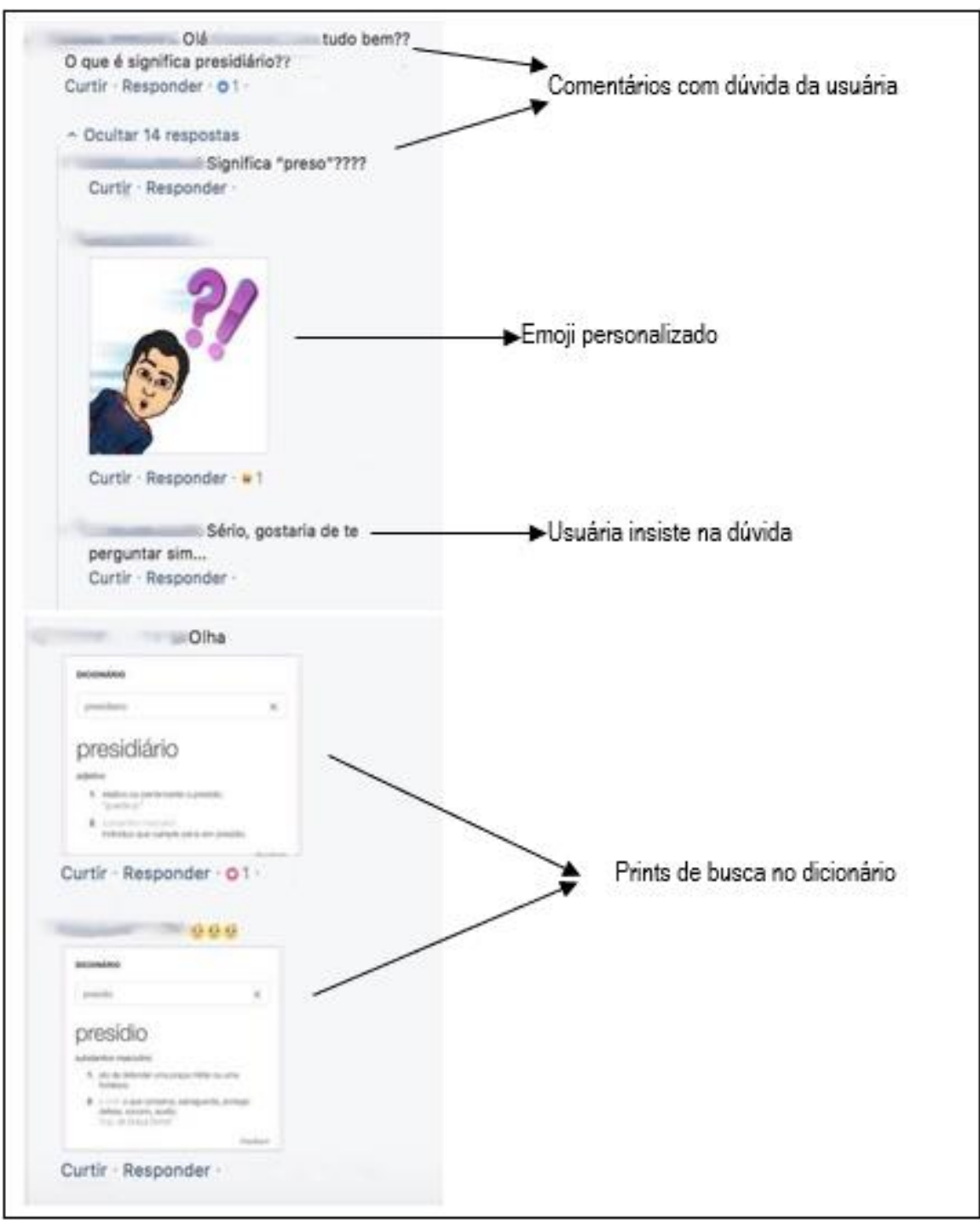

Fonte: dados coletados pela pesquisadora na página do usuário.

O comentário com emoji apontado na Figura 5 nos permite destacar um outro aspecto interessante da interação, pois logo após o professor surdo ter lançado mão da estratégia semiótica de inserção de um comentário com recurso visual, outros interlocutores que o seguiram também apresentaram comentários com conteúdos visuais, tais como os dois prints do dicionário anteriormente apresentados e alguns memes do expresidente Lula como presidiário, exemplificados a seguir na Figura 6. Dessa maneira, a escolha semiótica do professor é mantida por alguns dos interlocutores, que, para além dos recursos linguísticos do português escrito, passam a compor seus comentários com outros recursos semióticos visuais, a partir do momento em que ele, primeiramente, faz uso de um recurso imagético. 
Figura 6 - Comentários com memes do ex-presidente Lula

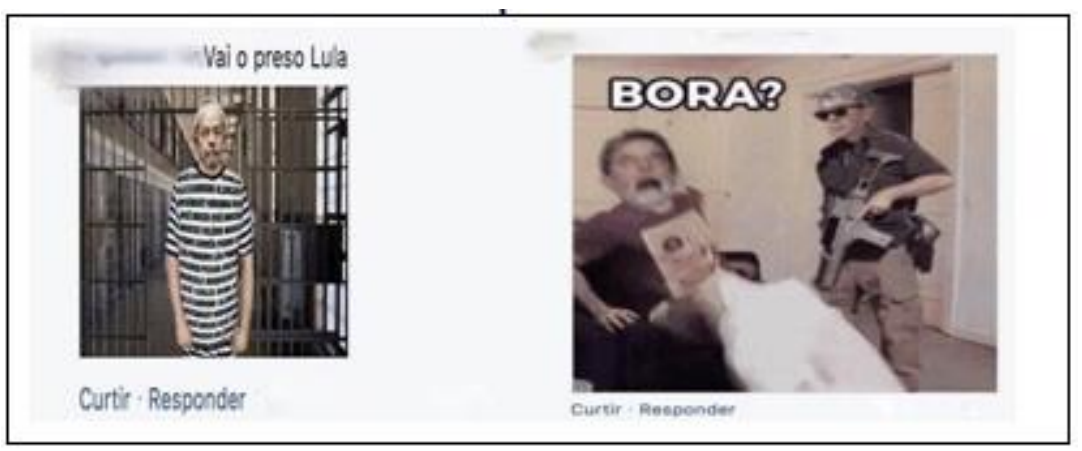

Fonte: dados coletados pela pesquisadora na página do usuário.

Estamos entendendo que esses memes acabaram por traduzir visualmente as ideias de "Lula presidiário" ou "Lula preso" presentes nos comentários com recursos linguísticos escritos que os antecederam. Com isso, analisamos, portanto, apoiados em Canagarajah (2017, p. 6), que o engajamento via comentários, ainda que enquadrado pelo recurso linguístico escrito, exibiu um funcionamento da linguagem que se constituiu a partir de uma coleção de recursos semióticos, alguns deles propiciados pelo próprio ambiente digital, mas utilizados estrategicamente na tentativa de alcançar o sucesso comunicativo: os recursos semióticos (prints e memes) indexicalizaram significados de outros recursos linguísticos (comentários em português escrito) para facilitar o entendimento. Nesse processo, observamos ainda que os recursos semióticos que compuseram os comentários dos interlocutores dão prosseguimento ao mesmo padrão de recursos da publicação original do professor, isto é, recursos linguísticos do português escrito e recursos semióticos imagéticos.

Esses aspectos se repetem em uma publicação do eixo temático informativo que também analisamos. Destacamos a postagem de um vídeo informativo todo em língua de sinais que explica sobre os códigos de observação presentes na Carteira Nacional de Habilitação Especial (CNH), mais especificamente sobre os códigos B e X, que se referem a pessoas com perda de audição. $\mathrm{O}$ vídeo foi gravado pelo próprio professor surdo, que aparece em meio primeiro plano durante toda a projeção sinalizando em libras (cf. Figura 7). Nessa publicação, novamente a escolha linguística do professor nos parece estar atrelada ao modo como ele percebe seus interlocutores, isto é, como indivíduos cujos repertórios sociossemióticos são constituídos também pela língua de sinais como parte desse repertório, de modo que essa escolha linguística é mais uma vez respeitada por alguns dos usuários, que fazem comentários também em língua de sinais.

No eixo informativo, a maior parcela das publicações do professor é feita em língua de sinais e mais diretamente orientada para seus interlocutores surdos. Analisando o conjunto de postagens desse eixo, ainda nos parece bastante provável que a publicação de materiais em língua de sinais tenha sido uma estratégia linguística do professor para instigar a atenção e garantir a compreensão de seus interlocutores. Isso porque, como o próprio professor surdo conta ao iniciar seu vídeo, no dia anterior à sua gravação e publicação, ele observou que diferentes jornais noticiaram sobre as mudanças nos critérios de suspensão das $\mathrm{CNHs}$ - o que incluía o caso específico de pessoas surdas que dirigem sem prótese auditiva - e que muitos surdos fizeram postagens abordando essa temática e expondo suas dúvidas. O professor surdo também destacou, logo no início de 
seu vídeo e na legenda-comentário escrita que o acompanha, como pode ser visto na Figura 7 a seguir, um chamado aos surdos para que atentem ao conteúdo do vídeo, asseverando, dessa maneira, em português escrito e em língua de sinais, a relevância de sua publicação.

\section{Figura 7 - Publicação composta por vídeo em língua de sinais e legenda-comentário}

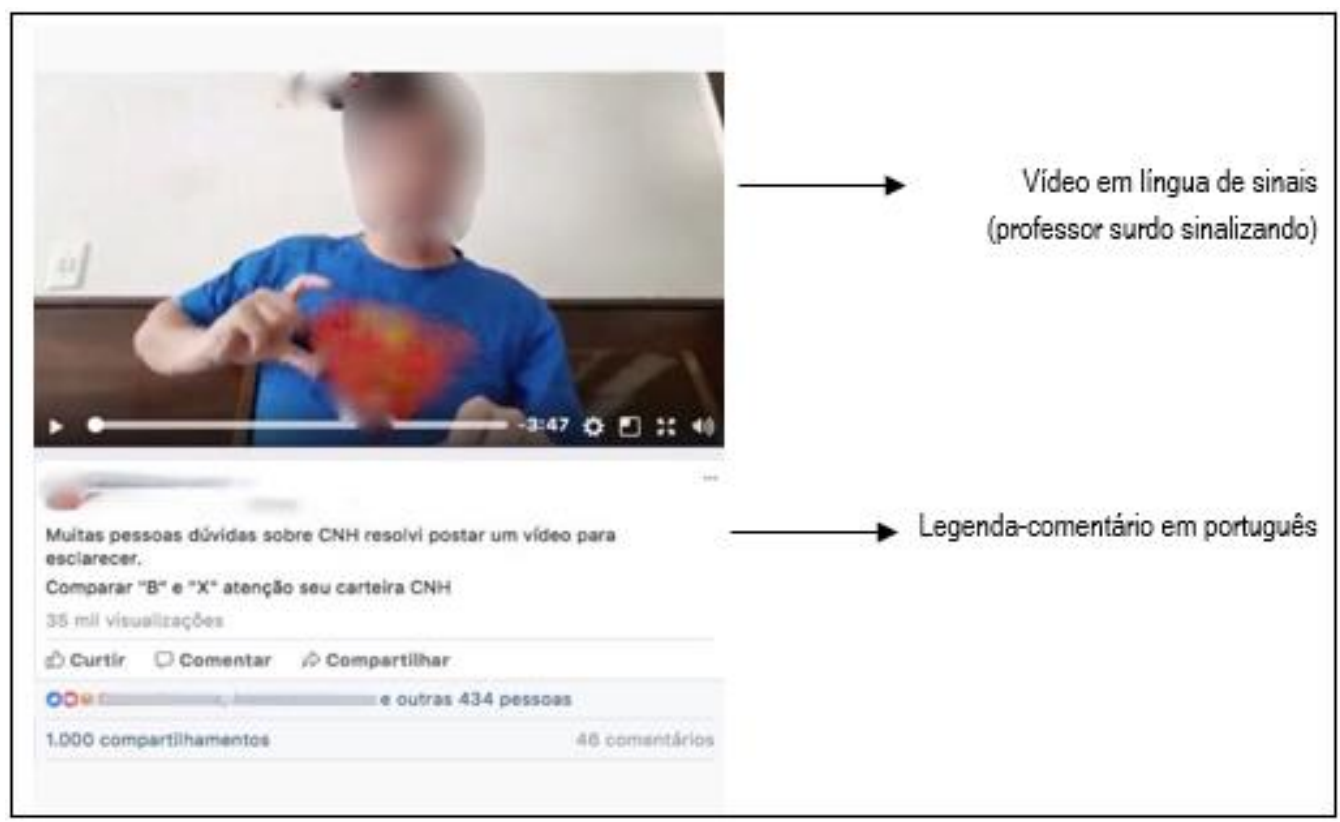

Fonte: dados coletados pela pesquisadora na página do usuário.

No primeiro minuto de seu vídeo, o professor surdo também dispôs de algumas imagens em formato de prints de notícias sobre a questão das CNH Especiais (conforme exemplos na Figura 8) como mais um recurso que assevera a importância da publicação do vídeo aos seus interlocutores. Ainda que os prints possam ser considerados recursos semióticos imagéticos, seus conteúdos são essencialmente textos verbais escritos. Assim, estamos entendendo que apresentá-los num vídeo que proporciona uma interlocução em língua de sinais dá possibilidade para que o professor surdo atue como tradutor de um conteúdo previamente veiculado por meio de recursos exclusivamente escritos.

\section{Figura 8 - Prints de notícias inseridos no vídeo em língua de sinais}

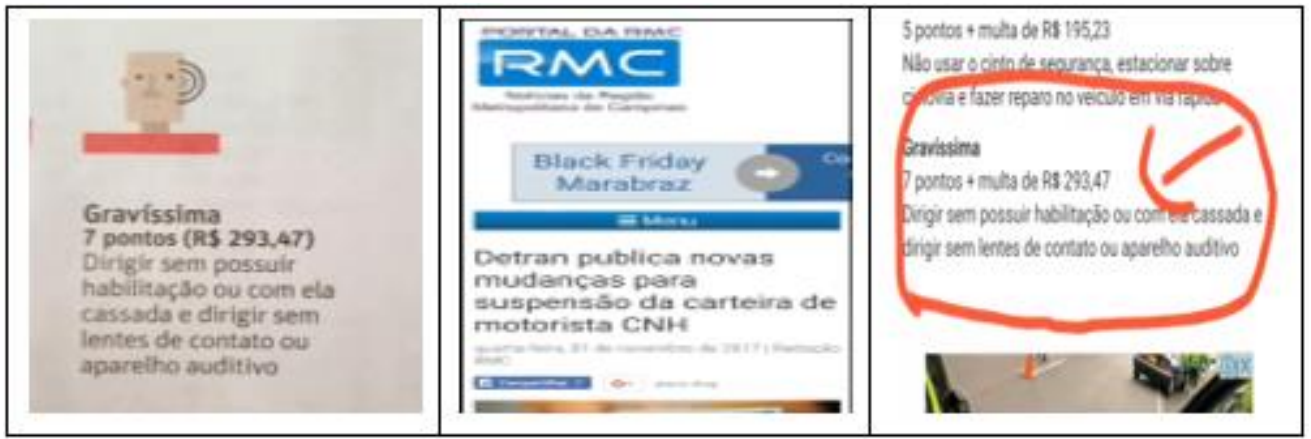

Fonte: dados coletados pela pesquisadora na página do usuário. 
No caso dessa publicação (Figura 7), portanto, é a língua de sinais que orienta o engajamento via comentários. A escolha linguística e semiótica do professor, como já dissemos, abriu possibilidades para que seus interlocutores também se engajassem em comentários que lançaram mão dos recursos linguísticos da língua de sinais e/ou do português escrito. Observamos, nessa interação, que os comentários em português escrito estão entremeados a comentários em língua de sinais que dialogam com o material postado pelo professor, a fim de esclarecer dúvidas que ainda restaram e até mesmo expandindo as explicações dadas pelo professor a outras situações não exploradas em seu vídeo. Além disso, recursos imagéticos, como a fotografia de uma $\mathrm{CNH}$, e a inserção de links também apareceram nos comentários feitos, como exibido na Figura 9. O próprio professor, inclusive, diante dos comentários em vídeo, respeita a escolha linguística de seus interlocutores, respondendo com mais um material de vídeo em língua de sinais.

\section{Figura 9 - Exemplo de interação via comentários com vídeos em língua de sinais, links e imagens}

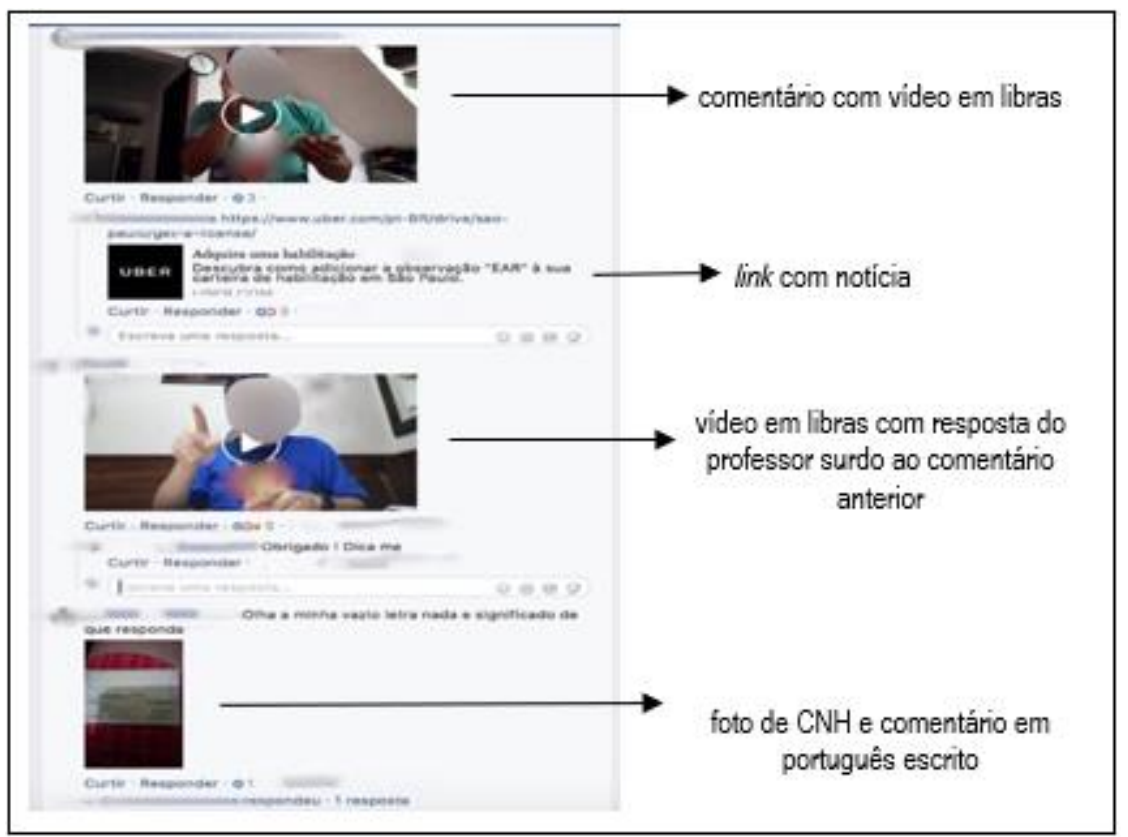

Fonte: dados coletados pela pesquisadora na página do usuário.

$\mathrm{Na}$ análise da publicação e do engajamento pelos comentários, percebemos que a interface entre o português e a língua de sinais, isto é, a interação entre esses dois recursos linguísticos aparece: a) na legenda escrita que é explicativa do conteúdo em libras do vídeo e serve também para chamar a atenção do interlocutor, b) pela tradução dos registros escritos (prints das notícias, exibidos na Figura 8) para a língua de sinais utilizada pelo professor no vídeo e, consequentemente, c) acontece naturalmente no engajamento pelos comentários à medida que os interlocutores parecem fazer as escolhas linguísticas que lhes são mais adequadas (ou mais confortáveis ${ }^{10}$ ) para compor seus comentários. Por esse mesmo motivo, é provável que, entremeados aos recursos linguísticos da língua de sinais ou do português escrito, apareçam nos comentários os

${ }^{10}$ Tal como no sentido atribuído à expressão língua de conforto. 
outros recursos semióticos (links e fotos, exibidos na Figura 9) cujas inserções tiveram, independentemente do recurso utilizado, a intenção de que os interlocutores se fizessem compreendidos.

Uma última publicação do professor que é representativa do conjunto de publicações aqui consideradas pode ser vista na Figura 10 e ilustra a interface entre os recursos linguísticos do português e da língua de sinais apresentando mais uma faceta dessa interação. Essa publicação é parte do eixo que categorizamos como sendo de temática pessoal, no qual o professor surdo publicou, dentre outros materiais, uma série de vídeos dele e de suas filhas sinalizando, em língua de sinais, os conteúdos imagéticos de alguns trechos de filmes.

Na Figura 10 vemos que a publicação do professor surdo é composta pelo vídeo de sua filha sinalizando logo abaixo da imagem em movimento do filme e também de uma legenda-comentário escrita ("Uauuu minha filha tem 7 anos interpretando o filme: [nome do filme].... Mais um dos meus genes herdados!!!”). Dentre os recursos da língua de sinais, os classificadores foram os mais utilizados na tradução e reapresentação da imagem em movimento do filme em língua de sinais pela menina surda. No entanto, ainda que a postagem do professor tenha sido composta pela publicação de um vídeo em língua de sinais, entendemos que foi a legenda em português que enquadrou todo o engajamento via comentários, guiando uma leitura esperada do material em vídeo. Para além de uma legenda informativa do conteúdo do vídeo, seus dizeres também marcaram uma representação do professor sobre as pessoas surdas diretamente relacionada a recursos específicos de seus repertórios sociossemióticos.

\section{Figura 10 - Publicação de vídeo em língua de sinais no eixo pessoal}

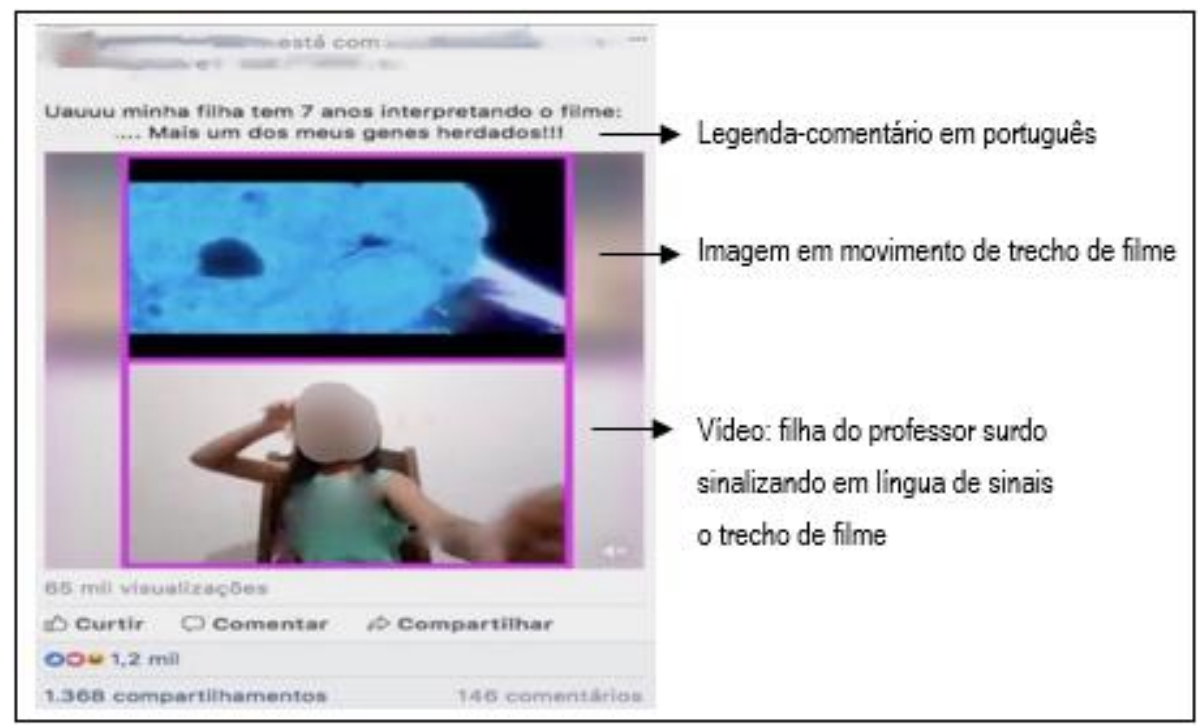

Fonte: dados coletados pela pesquisadora na página do usuário.

Quando o professor inicia sua legenda-comentário com a interjeição "Uauuu”, ele expressa satisfação ao ver e divulgar em vídeo a ação de sua filha em língua de sinais. Nesse sentido, entendemos que há não só a valorização da língua em si, como dos classificadores que, como já dissemos, são os recursos da língua de sinais mais utilizados. Os classificadores, conforme Campello (2008), são elementos marcadores na libras que 
funcionam como representação visual e linguística daquilo que se percebe visualmente. A língua de sinais, por ser uma língua visual e, sobretudo os classificadores, pela relação direta com os estímulos visuais do mundo, são entendidos como elementos que contribuem para a (re)definição da visualidade do surdo (cf. CAMPELLO, 2008). Sendo assim, ao considerarmos, em alinhamento a Campello (2008), que os classificadores são elementos de mapeamento visual em funcionamento na língua de sinais e que podem definir a visualidade do surdo, entendemos que a valorização da tradução do filme com classificadores da língua de sinais na legenda-comentário é também, por consequência, a valorização da visualidade da pessoa surda sinalizadora que utiliza esse recurso nas suas práticas comunicativas, característica essa que, na perspectiva do professor, poderia ser até mesmo uma herança genética das pessoas surdas, como ele mesmo segue dizendo na legenda-comentário: "Mais um dos meus genes herdados!!!".

Dovchin e Pennycook (2018) destacam que, no contexto social e comunicativo do Facebook, a partir de práticas linguísticas mixadas, os usuários podem negociar e organizar suas representações e identificações, sejam elas fluidas ou fixas. O que vemos, no caso dessa última publicação analisada, é que o professor realizou a postagem de um vídeo rico em classificadores da língua de sinais e enalteceu esse recurso com uma legenda em português. Ponderamos que, ainda que não tenha sido intencional, essa foi uma estratégia linguística que atingiu um público maior (surdos e ouvintes, inclusive) ao ressaltar aspectos que para o professor são significativos da língua de sinais e constitutivos da visualidade surda: o intenso engajamento do público com $65 \mathrm{mil}$ visualizações, 1.200 curtidas e/ou reações ao vídeo, 1.368 compartilhamentos e, sobretudo, os 146 comentários (dados que podem ser visualizados na Figura 10) foram enquadrados pelo recurso linguístico do português presente na legenda-comentário e isso significou, a nosso ver, que no caso dessa publicação, foi o recurso linguístico do português que acabou funcionando como uma lente de leitura do material postado e disparador do engajamento via comentários. Os usuários, em seus comentários, parabenizaram a sinalização apresentada no vídeo, bem como fizeram menção e apontaram o uso dos classificadores como sendo um aspecto bastante positivo ${ }^{11}$ do desenvolvimento linguístico da criança. Todos os comentários foram realizados em português escrito e marcaram percepções sobre a língua de sinais e as pessoas surdas que partilharam da mesma representação que o professor surdo exibiu em sua legendacomentário.

Para finalizar, entendemos que, nas publicações dos dois vídeos em língua de sinais (Figuras 7 e 10), o engajamento e as interações do público também se dão a partir de uma coleção de recursos, no sentido de Canagarajah (2017). Essa coleção é composta por recursos linguísticos que indexicalizam significados de outros recursos semióticos e viceversa - e também, sobremaneira, na interface do português com a língua de sinais: no vídeo informativo em libras (Figura 7), a adição de uma legenda-comentário em português escrito reapresenta o conteúdo dito em língua de sinais no vídeo, assevera a importância e chama a atenção dos interlocutores para o assunto tratado, ao mesmo tempo que o conteúdo em língua de sinais traduz os elementos em português escrito das notícias de jornais (Figura 8). Já no vídeo de interpretação do filme em língua de sinais (Figura 10), a língua de sinais traduz uma imagem em movimento de um filme, mas é o recurso linguístico do português escrito que enquadra a interação do professor com seus

\footnotetext{
${ }^{11}$ Para discussões sobre representações e valor indexical atribuído aos classificadores, ver Nogueira (2015).
} 
interlocutores: a) quando o conteúdo em português da legenda-comentário engaja e guia a leitura dos interlocutores, em especial para aspectos do vídeo que o professor surdo relaciona diretamente com representações sobre a língua de sinais (valorização desse recurso linguístico e dos classificadores) e sobre a pessoa surda (utilização de recursos altamente visuais da língua de sinais por meio de uma visualidade surda herdada geneticamente) e b) quando os comentários dos usuários, em português escrito, reiteram e ratificam essas representações.

\section{CONSIDERAÇÕES FINAIS}

A análise das publicações do professor surdo na rede social Facebook durante o ano de 2017 e, em específico, das três publicações que destacamos na seção anterior, nos deram indicações sobre as estratégias linguísticas e semióticas e os repertórios sociossemióticos dos interlocutores quando em situações de interação em ambiente digital online. Nesse processo, iluminaram-se aspectos que se referem à interface, no sentido de interação, entre recursos linguísticos em português e em língua de sinais.

Como o corpus de análise compôs-se a partir de publicações em uma rede social online, levamos em consideração, pela característica própria das interfaces digitais, que as postagens constituíram-se por textos de caráter multissemiótico e que, portanto, a construção de um quadro dos repertórios sociossemióticos seria influenciado por esse aspecto. Essa consideração, entretanto, não minorou a possibilidade de observamos especificidades no que se refere ao repertório semiótico do professor surdo, de seus interlocutores e as decorrentes estratégias de linguagem. Quando mais de um recurso estava sendo utilizado, observamos o respeito em relação às escolhas linguísticas e semióticas dos interlocutores. Além disso, os recursos constitutivos das postagens do professor anteciparam representações sobre seus interlocutores surdos e seus repertórios sociossemióticos. Ao mesmo tempo, tais escolhas linguísticas e semióticas feitas pelo professor também abriram espaço para negociação e orientação de representações sobre a pessoa surda e os recursos linguísticos do português e da língua de sinais por parte de seus interlocutores.

A interface dos recursos linguísticos do português e da língua de sinais constitui-se como parte de um conjunto maior de estratégias de linguagem constitutivas de interações translíngues, no sentido de Canagarajah (2017). Ora a língua de sinais, ora o português serviu como lente de leitura do material postado e funcionou como elemento de enquadramento do engajamento via comentários e da (re)construção de representações pelos interlocutores:

1.Na publicação com recurso linguístico do português mais recurso visual imagético (postagem do Lula), o enquadramento e orientação do engajamento com a postagem dãose pelo português; a língua de sinais funciona como lente de leitura dos elementos em português e há negociação de representações sobre o recurso linguístico do português e sobre a pessoa surda em relação ao domínio desse recurso.

2.Na publicação em língua de sinais com legenda-comentário em português (postagem de vídeo em libras sobre $\mathrm{CNH}$ ), a legenda-comentário apenas reapresenta o que está sendo dito em libras no vídeo, portanto, o enquadramento e orientação do engajamento com a postagem dão-se prioritariamente pela língua de sinais; a interlocução em língua de sinais 
funciona como tradução de elementos linguísticos em português (prints de notícias) e há mixagem entre português, língua de sinais e outros recursos semióticos como estratégia natural de intercompreensão.

3.Na publicação em língua de sinais com legenda-comentário em português (postagem do vídeo de tradução do filme em libras), a legenda-comentário em português acrescenta informações que guiam a leitura do interlocutor, portanto, a língua de sinais funciona como tradução de elementos visuais da imagem em movimento do filme, enquanto o enquadramento e orientação do engajamento com a postagem dão-se pelo português escrito da legenda-comentário (o português é a lente de leitura, nesse caso) e possibilitam a negociação e organização de representações sobre a língua de sinais (sobretudo o recurso dos classificadores) e da pessoa surda (visualidade) em comentários escritos em português.

A análise das estratégias linguísticas e semióticas anteriormente apresentadas suscitou seguirmos em favor do conceito de interface do português e da língua de sinais no sentido de uma interação entre esses recursos constitutiva de práticas translíngues nas quais estão envolvidas pessoas surdas cujos repertórios sociossemióticos são constituídos por esses e outros recursos mais. Essa interface, portanto, passa longe de ser entendida como um aspecto transitório da comunicação de pessoas surdas ou como uma mera interferência de uma língua na outra, a ser ultrapassada ou abandonada à medida que o domínio esperado para um ou outro recurso é alcançado.

Acreditamos ainda que a análise evidencia um conceito de multilinguismo mais complexo, diretamente relacionado a construções político-ideológicas sobre língua(gem) e sobre a pessoa surda, que contribuem para a produção de entendimentos sobre a complexidade constitutiva dos contextos bi/multilíngues (cf. CAVALCANTI, 2011) e iluminam a potencialidade de estudos que focalizem a comunicação e a produção de significados a partir do conceito de repertórios sociossemióticos como um quadro de referência (cf. KUSTERS et al., 2017), movimento que acreditamos ser importante para os estudos sobre a comunicação de pessoas surdas.

De uma perspectiva mais pedagógica, concebemos os ambientes digitais online, como é o caso do Facebook, como espaços privilegiados para observação dos modos de engajamento contemporâneos, marcados por uma constituição multilíngue e multimodal de recursos. Desse modo, consideramos relevante aos professores de língua estarem atentos ao fato de que os espaços das redes sociais não estão deslocados de um sistema maior de atividades translíngues (CANAGARAJAH, 2017) que, portanto, podem garantir uma boa maneira de compreender as práticas de língua(gem) e as construções e reconstruções identitárias dos alunos cujas participações online e offline não se encontram descoladas, mas intricadamente tecidas.

\section{REFERÊNCIAS}

BLACKLEDGE, A. Monolingual ideologies in multilingual states: language, hegemony and social justice in Western liberal democracies. Estudios de Sociolingüística, v. 1, n. 2, p. 25-45, 2000.

BLOMMAERT, J. A sociolinguistics of globalization. Cambridge: Cambridge University Press, 2010. BLOMMAERT, J.; RAMPTOM, B. Language and superdiversity. In: BLOMMAERT, J.; RAMPTON, B.; SPOTTI, M. Language and superdiversities. Diversities. Online journal published by UNESCO \& MPI MMG, v. 13, n. 2, 2011.

BRASIL. DECRETO $n^{\circ} 5.626$ de 22 de dezembro de 2005. Regulamenta a Lei $\mathrm{n}^{\circ} 10.436$, de 24 de abril de 2002, que dispõe sobre a Língua Brasileira de Sinais - Libras, e o art. 18 da Lei no 10.098 , de 19 de 
dezembro de 2000. Disponível em: <http://www.planalto.gov.br/ccivil_03/_ato2004-

2006/2005/decreto/D5626.htm>. Acesso em: 3 maio 2018.

BRASIL. LEI $n^{\circ} 10.436$ de 24 de abril de 2002. Dispõe sobre a Língua Brasileira de Sinais - Libras e dá outras providências. Disponível em: 〈http://portal.mec.gov.br/seesp/arquivos/pdf/lei10436.pdf〉. Acesso em: 3 maio 2018.

BROCHADO, S. M. D. A apropriação da escrita por crianças surdas usuárias da língua de sinais brasileira. 2003. Tese (Doutorado em Letras) - Universidade Estadual Paulista, Assis, 2003.

CAMPELLO, A. R. S. 2008. Aspectos da visualidade na educação de surdos. Tese (Doutorado em Educação) - Universidade Federal de Santa Catarina, Florianópolis, 2008.

CANAGARAJAH, S. Translingual practice as spatial repertoires: expanding the paradigm beyond structuralist orientations. Applied Linguistics, v. 39, n. 1, p. 31-54, 2017. Disponível em:

<http://academic.oup.com/applij/article-abstract/doi/10.1093/applin/amx041/4626948>. Acesso em: 14 nov. 2017.

CAVALCANTI, M. C. Multilinguismo, transculturalismo e o (re)conhecimento de contextos minoritários, minoritarizados e invisibilizados: o que isso tem a ver com a formação de professores e com professores em serviço? In: MAGALHÃES, M. C. C.; FIDALGO, S. S. (Org.). Questões de método e de linguagem na formação docente. Campinas: Mercado de Letras, 2011, p. 171-185.

CAVALCANTI, M. C.; SILVA, I. R. Transidiomatic practices in a deaf-hearing scenario and language ideologies. Revista da Anpoll, n. 40, p. 33-45, 2016. Disponível em:

<https://revistadaanpoll.emnuvens.com.br/revista/article/view/1013>. Acesso em: 5 abr. 2018.

DOVCHIN, S.; PENNYCOOK, A. Digital metroliteracies: space, diversity, and identity. In: MILLS, K. A. et al. (Eds.). Handbook of writing, literacies, and education in digital cultures. New York: Routledge, 2018. Disponível em:

<https://books.google.com.br/books?id=af0wDwAAQBAJ\&pg=PT323\&lpg=PT323\&dq=semiotic+resou rces+facebook\&source $=$ bl\&ots=mlu7qR1Epp\&sig=63mKAVKyHQ6gEilYhYDWZ2DUzsM\&hl=ptBR

$\& s a=X \& v e d=0 a h U K E w i F w 6 S I y o r a A h U G C p A K H f 76 B \_o Q 6 A E I Q T A D \# v=$ onepage \&q=semiotic\%20res ources\%20facebook\&f=true >. Acesso em: 10 fev. 2018.

FERNANDES, S. Avaliação em língua portuguesa para alunos surdos: algumas considerações. In: PARANÁ. SECRETARIA DE ESTADO DA EDUCAÇÃO. Grupos de estudos por área. Curitiba, agosto de 2007. Disponível em:

<http://www.diadiaeducacao.pr.gov.br/portals/portal/institucional/dee/dee_surdez.php>. Acesso em: 2 jun. 2018.

GESUELI, Z. M. Língua de Sinais e aquisição da escrita. In: SILVA, I. R.; KAUCHAKJE, S.; GESUELI, Z. M. (Org.). Cidadania, surdez e linguagem: desafios e realidades. São Paulo: Plexus, 2003. p. 147-159.

A escrita como fenômeno visual nas práticas discursivas de alunos surdos. In: LODI, A. C. B.;

MÉLO, A. D. B.; FERNANDES, E. Letramento, bilinguismo e educação de surdos. Porto Alegre: Mediação, 2012. p. 173-186.

GIORDANI, L. F. Encontros e desencontros da língua escrita. In: LODI, A. C. B.; MÉLO, A. D. B.; FERNANDES, E. Letramento, bilinguismo e educação de surdos. Porto Alegre: Mediação, 2012. p. 135152.

KARNOPP, L. B. Práticas de leitura e escrita entre surdos. In: LODI, A. C. B.; MÉLO, A. D. B.; FERNANDES, E. Letramento, bilinguismo e educação de surdos. Porto Alegre: Mediação, 2012. p. $153-$ 172.

KUSTERS, A. Gesture-based customer interactions: deaf and hearing Mumbaikars' multimodal and metrolingual practices. International Journal of Multilingualism, 2017. Disponível em: <http://dx.doi.org/10.1080/14790718.2017.1315811>. Acesso em: 20 ago. 2017.

KUSTERS, A. et al. Beyond languages, beyond modalities: transforming the study of semiotic repertoires. International Journal of Multilingualism, 2017. Disponível em: <http://dx/doi.org/10.1080/14790718.2017.1321651>. Acesso em: 20 ago. 2017.

MARTIN-JONES, M.; BLACKLEDGE, A.; CREESE, A. The Routledge Handbook of Multilingualism. London and New York: Routledge, 2012.

MOITA LOPES, L. P. Pesquisa interpretativista em Linguística Aplicada: a linguagem como condição e solução. D.E.L.T.A., v. 10, n. 2, p. 329-338, 1994.

(Org.). Por uma linguística indisciplinar. São Paulo: Parábola, 2006.

NOGUEIRA, A. S. 2015. “O surdo não ouve, mas tem olho vivo” - a leitura de imagens por alunos surdos em tempos de práticas multimodais. Tese (Doutorado em Linguística Aplicada) - Universidade 
Estadual de Campinas, Campinas, 2015. Disponível em: <http://repositorio.unicamp.br/jspui/handle/REPOSIP/269526>. Acesso em: 29 set. 2018.

Práticas de letramento multimodais em ambiente digital: uma possibilidade para repensar a educação de surdos. Revista Intercâmbio, São Paulo, v. XXVIII, p. 19-45, 2014. Disponível em: <https://revistas.pucsp.br/index.php/intercambio/article/view/19639>. Acesso em: 29 set. 2018.

PEIXOTO, R. C. Algumas considerações sobre a interface entre a Língua Brasileira de Sinais e a Língua Portuguesa na construção inicial da escrita pela criança surda. Cad. Cedes, Campinas, v. 26, n. 69, p. $205-$ 229, 2006. Disponível em: <http://www.scielo.br/pdf/\%0D/ccedes/v26n69/a06v2669.pdf>. Acesso em: 7 jan. 2018.

PEREIRA, M. C. C. Papel da língua de sinais na aquisição da escrita por estudantes surdos. In: LODI, A. C. B.; MÉLO, A. D. B.; FERNANDES, E. Letramento, bilinguismo e educação de surdos. Porto Alegre: Mediação, 2012. p. 235-246.

SIGNORINI, I. Do residual ao múltiplo e ao complexo: o objeto da pesquisa em Linguística Aplicada. In: SIGNORINI, I.; CAVALCANTI, M. C. (Org.). Linguística Aplicada e transdisciplinaridade: questões e perspectivas. Campinas: Mercado de Letras, 1998. p. 99-110.

\section{Recebido em: 06/07/18. Aprovado em: 24/09/18.}

Title: Portuguese interface with sign language in publications of a deaf professor in social network

Author: Aryane Santos Nogueira

Abstract: The article focuses on the interface of Portuguese with sign language in publications posted by a deaf professor on his personal page on Facebook social network during the year 2017. The motivation for the chosen scenario was the possibility of observing communicative practices that constitute the social participation of deaf users. From a qualitative-interpretative analysis, theoretically informed by an expanded sociolinguistic perspective of the concept of language, we explore the set of publications and the audience engagement through comments to show specificities about the interaction between linguistic resources of Portuguese and sign language used. These interactions are also intersected by semiotic features widely used on the internet (images, memes, gifs), and show a more complex concept of multilingualism interwoven with ideological constructions about language and deaf people.

Keywords: Deafness. Multilingualism. Portuguese. Sign Language. Online digital spaces.

Título: Interface del portugués con la lengua de señales en publicaciones de un profesor sordo en rede social

\section{Autora: Aryane Santos Nogueira}

Resumen: El artículo focaliza la interface del portugués con la lengua de señales en publicaciones realizadas por un profesor sordo en su página personal en la red social Facebook, durante el año de 2017. La motivación para el recorte ocurrió por la posibilidad de observación de prácticas comunicativas constitutivas de la participación social de usuarios sordos. Desde un análisis cualitativo-interpretativo, informado teóricamente por una concepción sociolingüística ampliada del concepto de lengua(je), explora el conjunto de publicaciones y el encajamiento del público por medio de comentarios para mostrar especificidades sobre la interacción que se establece entre los recursos lingüísticos del portugués y de la lengua de señales empleados. Intersectadas también por recursos semióticos ampliamente utilizados en internet (imágenes, memes, gifs), tales interacciones evidencian un concepto de multilingüismo más complejo, entreverado por construcciones ideológicas sobre la lengua(je) y sobre la persona sorda.

Palabras-clave: Sordez. Multilingüismo. Portugués. Lengua de señales. Ambiente digital en línea.

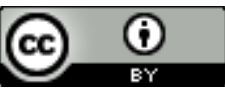

Este texto está licenciado com uma Licença Creative Commons Atribuição 4.0 Internacional 